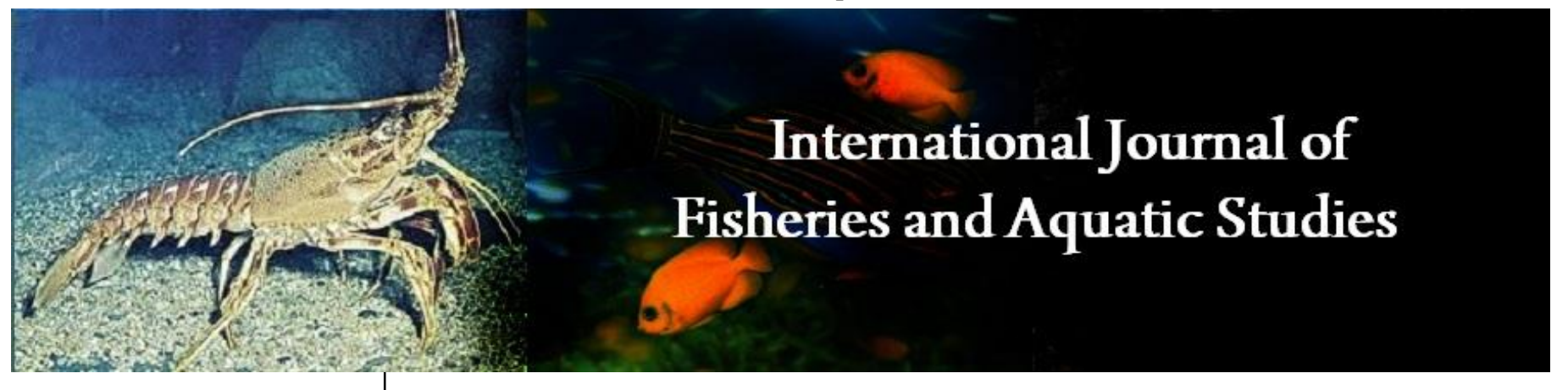

E-ISSN: 2347-5129

P-ISSN: 2394-0506

(ICV-Poland) Impact Value: 5.62

(GIF) Impact Factor: 0.549

IJFAS 2021; 9(2): 34-39

(C) 2021 IJFAS

www.fisheriesjournal.com

Received: 16-01-2021

Accepted: 18-02-2021

Barthazar Masengesho

Cam Ranh Centre for Tropical

Marine Research and

Aquaculture, Institute of

Aquaculture, Nha Trang

University, No 2 Nguyen Dinh

Chieu Street, Nha Trang City,

Vietnam

Minh Van Nguyen

Cam Ranh Centre for Tropical

Marine Research and

Aquaculture, Institute of

Aquaculture, Nha Trang

University, No 2 Nguyen Dinh

Chieu Street, Nha Trang City,

Vietnam

Hung Duc Pham

Cam Ranh Centre for Tropical

Marine Research and

Aquaculture, Institute of

Aquaculture, Nha Trang

University, No 2 Nguyen Dinh

Chieu Street, Nha Trang City,

Vietnam

Minh-Hoang Le

Cam Ranh Centre for Tropical

Marine Research and

Aquaculture, Institute of

Aquaculture, Nha Trang

University, No 2 Nguyen Dinh

Chieu Street, Nha Trang City,

Vietnam
Corresponding Author:

Minh-Hoang Le

Cam Ranh Centre for Tropical

Marine Research and

Aquaculture, Institute of

Aquaculture, Nha Trang

University, No 2 Nguyen Dinh

Chieu Street, Nha Trang City,

Vietnam

\section{Effects of fish size and feeding rations on growth performance and immune responses of Waigieu sea perch (Psammoperca waigiensis) at juvenile stage}

\author{
Barthazar Masengesho, Minh Van Nguyen, Hung Duc Pham and Minh- \\ Hoang Le
}

DOI: https://doi.org/10.22271/fish.2021.v9.i2a.2438

\begin{abstract}
Waigieu Sea perch (Psammoperca waigiensis) is one of the most commercially and nutritionally important species. However little research has been done to explore the fish size, feeding rations on growth performance and immune responses of Waigieu Sea perch at juvenile stage. This paper derivers form an in depth study of the effect of feeding rate on growth performance and heamatological parameters. 198 fish of an average initial weight of $(17 \pm 0.01 \mathrm{~g}$ and $8.5 \pm 0.01 \mathrm{~cm})$ for group of small size and an average initial weight of $(20 \pm 0.21 \mathrm{~g}$ and $11 \pm 0.2 \mathrm{~cm})$ for group of big size. Juvenile were collected from a luong son hatchery were stocked in 18 tanks $(20 \mathrm{~L})$ during 42 days. All fish were fed the same diets contained $44 \%$ crude protein at feeding rate of 3,5 and $7 \%$ of body weight with three replicates per treatment fish were fed twice per day at 08:00 and 16: $0 \mathrm{hr}$. Results revealed that feeding rate tested did not influence survival and there was a significant differences in growth performance and heamotological parameters in both fish size with feeding rates at $5 \%(P<0.05)$. There was no significant difference $(p>0.05)$ in whole body composition in all feeding trails. Nevertheless feeding rate of $5 \%$ of body weight daily can't be considered as the optimal feeding rate for Waigieu Sea perch further research should be done on different size and different feeding rate to enhance fish growth and heamatological parameters.
\end{abstract}

Keywords: Waigieu seaperch, Psammoperca waigiensis, fish size, feeding rate, growth rate, immune

\section{Introduction}

Waigieu sea perch (Psammoperca waigiensis) is a marine fish distributed along the coasts of tropical countries in the Asia-Pacific region (Le and Brown 2016, Le et al. 2011, Le et al. 2014a, Le et al. 2014b, Le and Pham 2017, Le and Pham 2018) ${ }^{[10,11,12,13,14,15]}$. Several studies have shown that Waigieu Sea perch are potential candidates for aquaculture and they appear good candidates for a variety of production systems. Early attempts to raise sea perch have been in cages, ponds, and indoor as well as outdoor recirculation systems. However there are few guidelines available that would allow development of formal business plans or cash/flow evaluations.

Feed costs are commonly one of the highest annual variable costs in aquaculture (SalgadoIsmodes et al. 2020) ${ }^{[21]}$. Inadequate feed inputs results in slower growth, slower time to market, and may compromise the immune system, while overfeeding increases cost of production and degrades water quality. Quantifying the near optimal feed rate for new and emerging aquaculture species is an important piece of information. Without this value and associated rates of weight gain, business plans cannot be accurately developed, and development of continuous production scenarios would be challenging (Rupasinghe and Kennedy 2006) ${ }^{[20]}$. However, optimal feeding rates are not constant throughout the growing cycle of food fish. Optimal feed rates vary at each stage of growth (Marimuthu et al. 2011) ${ }^{[17]}$. Optimal feed rates are commonly highest at early ages and if those values are known, satiation feeding approaches can be tailored to daily and longer term changes in voluntary consumption, which should gradually decrease over the course of the growing period. The objective of this study was to evaluate the effects of fish size and feeding rates on growth performance and immune responses of Waigieu seaperch juveniles. 


\section{Materials and Methods \\ Ethics statement}

Based on the National Regulations for the Use of Animals in Research in Vietnam: The Law of Animal Husbandry of Vietnam, 2018 and The Government Decree 32/2006/ND-CP on Management of Endangered, Precious, and rare Species of Wild Plants and Animals, experiments on waigieu seaperch are exempt from ethical approval requirements. However, the authors have implemented their best practice following the guidelines of using animals in research based on EU directive 2010/63.

\section{Fish preparation}

Fertilized eggs were collected via artificial reproduction. Eggs were incubated in 200-L fiberglass tanks. After hatching, larvae were transferred to cement tanks $\left(5 \mathrm{~m}^{3}\right)$. Larvae were fed a combination of enriched-rotifers and Artemia before transfer to a commercial diet. After 3 months, juveniles (17 $20 \mathrm{~g} / \mathrm{fish}$ ) were collected and transported to the wet laboratory in Nha Trang University for the experiment. Juveniles were acclimated to experimental conditions for 1 week before the experiment. During acclimatization, fish were fed a commercial diet containing $44 \%$ protein and $10 \%$ lipid (C5001, UP, Vietnam).

\section{Experimental system}

An indoor research trial was conducted in the wet laboratory of Nha Trang University, Vietnam over a period of 42 days. Juveniles were stocked in fiberglass tanks (200 L/tank) arranged in series with 3 replicates per treatment. All tanks were connected to recirculating water system. The water was exchanged $30 \%$ every day and $90 \%$ every week. Each tank had an air-diffuser to maintain oxygen at no less than 5.5 $\mathrm{mg} / \mathrm{L}$ and a constant flow rate of $5 \mathrm{~L} / \mathrm{min}$.

\section{Experimental design}

Before the feeding experiment commenced, all fish were starved for 24 hours and anaesthetized with tricaine methanesulfonate (MS-222; Argent Chemical, Redmond, WA) and individually weighed. Two size classes of juveniles (17 and $20 \mathrm{~g}$ ) were identified upon weighing, and each size class was randomly distributed into 18 tanks with 9 tanks/size at the density stocking of 11 fish per tank. Each feeding rate (3\%, $5 \%$ or $7 \%$ ) was assigned to three randomly positioned tanks in each size.

Temperature, dissolved oxygen and $\mathrm{pH}$ in the rearing water were measured daily. Total ammonia was monitored with the $\mathrm{NH}_{3} / \mathrm{NH}_{4}{ }^{+}$test kit (Mars Fish Care, Chalfont, PA, USA), dissolved oxygen determined using the $\mathrm{DO}$ meter, $\mathrm{pH}$, using a pH meter Q400A, and salinity measured by hand-held refractometer S/Mill-E (Atago Co., Tokyo, Japan). The fish were hand-fed twice daily at 8:00 and 16:00 for 6 weeks. After feeding, the uneaten feed was collected by siphoning. During the experiment, ammonia was less than $0.5 \mathrm{mg} / \mathrm{L}, \mathrm{pH}$ ranged from $7.5-8.0$, while the dissolved oxygen and water temperature were $6.5 \pm 0.5 \mathrm{mg} / \mathrm{L}$ and $28 \pm 0.7{ }^{\circ} \mathrm{C}$, respectively.

\section{Sample collection}

At the end of the experiments, all fish were individually weighed. Before weighing, fish were starved for 24 hours and anaesthetized with tricaine methanesulfonate (MS-222; Argent Chemical, Redmond, WA). Three fish in each tank were used to remove muscle tissues for proximate composition. Blood samples from three fish per tank were collected by puncturing their caudal vein using a syringe and transferred to BD Vacutainer (with K2E $5.4 \mathrm{mg}$, United Kingdom) for hematological analysis.

\section{Proximate composition}

Crude protein content was analyzed using Kjeltec Auto 1030 analyzer (Foss Tecator, Höganäs, Sweden), and crude lipid was extracted with petroleum ether extraction in a Soxhlet extraction system. Moisture was determined by drying at 105 ${ }^{\circ} \mathrm{C}$ (Thermotec 2000, Contherm Scientific, and Hutt, New Zealand). Ash was determined by combustion at $550{ }^{\circ} \mathrm{C}$ for $24 \mathrm{~h}$ in an electric furnace (Carbolite, Sheffield, UK).

\section{Hematological analysis}

Blood samples were drawn through caudal vein of each fish using a syringe rinsed with heparin from one fish in each tank (3 fish per treatment) and transferred to individual sterilized vials (at $4{ }^{\circ} \mathrm{C}$ ) containing $10 \mu \mathrm{L}$ heparin, respectively. The analysis for white blood cells (WBC), red blood cells (RBC), hematocrit $(\mathrm{Hct})$, hemoglobin $(\mathrm{Hb})$, mean corpuscular volume $(\mathrm{MCV})$, mean corpuscular hemoglobin $(\mathrm{MCH})$, and mean corpuscular hemoglobin concentration (MCHC) was done on the Systemex, XT-1800i blood analyzer. Plasma triglycerides and plasma protein were analyzed on a 600 DxC General Chemistry Analyzer.

\section{Calculation and statistical analysis}

The following parameters in all tanks were calculated using the following equations:

Survival $(\%)=$ final fish number / initial fish number*100

Weight gain $(\mathrm{WG}$ g/fish $)$ = final weight - initial weight

Specific Growth Rate $($ SGR \%/day) $=[($ Ln FBW - Ln IBW)/feeding period (days) $]^{*} 100$

Feed Conversion Ratio $(\mathrm{FCR})=(\mathrm{g}$ diet consumed $) /(\mathrm{g}$ final biomass $-\mathrm{g}$ initial biomass $+\mathrm{g}$ dead fish $)^{-1}$.

Protein Efficiency Ratio $(\mathrm{PER})=\left(\mathrm{BW}_{2}-\mathrm{BW}_{1} *\right.$ protein fed $\left.{ }^{1}\right) * 100$

Feed intake $(\mathrm{FI})=$ Feed used - uneaten feed

Mean corpuscular volume $(\mathrm{MCV})=$ Hematocrit/Red blood cell

Mean corpuscular hemoglobin concentration $(\mathrm{MCHC})=$ Hemoglobin/Hematocrit

All data were expressed as mean \pm SD unless otherwise specified. In experimental 1, all data were analyzed by twoway ANOVA to determine the effects of fish size, feeding rate and the interaction between fish size and feeding rate on growth, feed utilization and proximate composition of Waigieu sea perch. To analyze the significant differences in feeding treatments, Duncan multiple comparison post hoc tests were employed using SPSS for Windows version 22 (IBM, New York, USA). The significant statistic was evaluated at $P<0.05$.

\section{Results \\ Growth and feed utilization}

It is evident from (Table 1) there was no significant effect offish size on the final body weight of waigieu sea perch after 6 weeks of feeding $(P>0.05)$. The FBW of waigieu sea perch was significantly affected by the feeding rate $(P<0.05)$. However, there was no interaction effect of fish size and feeding rate on the FBW of fish $(P>0.05)$. Fish fed with the feeding rate of $5 \% \mathrm{BW}$ had significantly higher $\mathrm{FBW}$ compared with fish fed with 7\%BWand 3\% BW. 
There were no significant effects of fish size on feed conversion ratio (FCR) $(P>0.05)$, but significantly effects on the feed intake (FI) and protein efficiency ratio (PER) $(P<0.05)$. The interactions between fish size and feeding rate also had no effects on the FI of waigieu sea perch $(P>0.05)$, but had effects on FCR and PER $(P<0.05)$. However, the feeding rate significantly affected FCR and PER of the fish $(P<0.05)$, but had no effect on the feed intake $(P>0.05)$, fish fed feeding rate of 3 and $7 \% \mathrm{BW}$ had significantly higher
FCR than those fed $5 \%$ of feeding rate. Whereas, fish fed feeding rate of 5\% BW had significantly higher PER than those fed 3 and $7 \%$ of feeding rates. The specific growth rate (SGR) and weight gain (WG) of weigieu sea perch was significantly affected by feeding rate and fish size $(p<0.05)$ however there was no interaction effect of fish size and feeding rate on SGR and WG $(p>0.05)$, the fish fed with the feeding rate of $5 \% \mathrm{BW}$ had significantly higher SPR and WG than fish fed with $7 \% \mathrm{BW}$ and $3 \% \mathrm{BW}$.

Table 1: Effects of fish size and feeding rate on growth and feed utilization of Waigieu Sea perch all fish readily accepted the experimental conditions and no fish died during the experiment period

\begin{tabular}{|c|c|c|c|c|c|c|}
\hline & FW (g/fish) & SGR (\%/day) & WG (g/fish) & FI (g/fish) & FCR & PER (\%) \\
\hline \multicolumn{7}{|c|}{ Treatments } \\
\hline SS3 & 26.88 & 1.09 & 9.77 & 19.37 & 1.97 & 1.15 \\
\hline SS5 & 33.11 & 1.59 & 16.11 & 23.45 & 1.46 & 1.56 \\
\hline SS7 & 29.67 & 1.32 & 12.67 & 23.04 & 1.82 & 1.25 \\
\hline BS3 & 29.44 & 0.92 & 9.44 & 17.92 & 1.90 & 1.20 \\
\hline BS5 & 33.78 & 1.25 & 13.78 & 20.66 & 1.50 & 1.52 \\
\hline BS7 & 31.89 & 1.11 & 11.89 & 22.88 & 1.94 & 1.18 \\
\hline Pooled SE & & & & & & \\
\hline & & Means of & effects of size & & & \\
\hline SS & 29.89 & $1.33^{\mathrm{b}}$ & 12.85 & 21.95 & 1.75 & 1.32 \\
\hline $\mathrm{BS}$ & 31.70 & $1.09^{\mathrm{a}}$ & 11.70 & 20.49 & 1.78 & 1.30 \\
\hline \multicolumn{7}{|c|}{ Mean of main effects of feeding rate } \\
\hline 3 & $28.17^{\mathrm{A}}$ & $1.00^{\mathrm{A}}$ & $9.61^{\mathrm{A}}$ & 18.64 & $1.94^{\mathrm{B}}$ & $1.18^{\mathrm{A}}$ \\
\hline 5 & $33.44^{\mathrm{C}}$ & $1.42^{\mathrm{C}}$ & $14.94^{\mathrm{C}}$ & 22.06 & $1.48^{\mathrm{A}}$ & $1.54^{\mathrm{B}}$ \\
\hline 7 & $30.78^{\mathrm{B}}$ & $1.21^{\mathrm{B}}$ & $12.29^{\mathrm{B}}$ & 22.96 & $1.88^{\mathrm{B}}$ & $1.21^{\mathrm{A}}$ \\
\hline \multicolumn{7}{|c|}{ Two-way ANOVA: P values } \\
\hline Fish size & 0.052 & 0.004 & 0.194 & 0.354 & 0.556 & 0.488 \\
\hline Feeding rate & 0.001 & 0.001 & 0.001 & 0.087 & 0.000 & 0.000 \\
\hline Fish size $\times$ Feeding rate & 0.630 & 0.573 & 0.601 & 0.783 & 0.273 & 0.347 \\
\hline
\end{tabular}

Values are displayed as mean of triplicate groups. Means with different alphabets $(\mathrm{a}, \mathrm{b})$ within a column indicate the significant differences $(P<$ $0.05)$ by means of the main effects of fish size. Means with different capital alphabets $(\mathrm{A}, \mathrm{B}, \mathrm{C})$ within a column indicate the significant differences $(P<0.05)$ by means of the main effects of feeding rate. SS: small size; BS: big size

\section{Proximate composition}

Table 2 showed that there was the less significant effect of fish size on the crude protein of waigieu sea perch after 6 weeks of feeding $(P<0.05)$. The $\mathrm{CP}$ of waigieu sea perch was also less significantly affected by the feeding rate $(P<0.05)$. However, there was no interaction effect of fish size and feeding rate on the $\mathrm{CP}$ of fish $(P>0.05)$. Fish fed with the feeding rate of $5 \% \mathrm{BW}$ had significantly high $\mathrm{CP}$ compared with fish fed with $3 \% \mathrm{BW}$ and $7 \% \mathrm{BW}$.

Crude lipid was significantly affected by fish size $(P<0.05)$. There was no significant effect on feeding rate $(P>0.05)$. However, interactions between fish size and feeding rate had higher significant effects on crude lipid $(P<0.05)$. Fish fed with a feeding rate of $5 \% \mathrm{BW}$ had significantly high $\mathrm{CL}$ compared with fish fed with $3 \% \mathrm{BW}$ and $7 \% \mathrm{BW}$.

There were no significant effects of fish size on moisture $(P>0.05)$. Higher significant effect on feeding rate $(p<0.05)$. However, interactions between fish size and feeding rate had no significant effects on moisture $(P>0.05)$. Fish fed with a feeding rate of $3 \% \mathrm{BW}$ had significantly high moisture compared with fish fed with 5\%BWand $7 \%$ BW.

There was effect fish size on the ash of waigieu sea perch after 6 weeks of feeding period $(P<0.05)$, but there were significantly effect on feeding rate $(P>0.05)$. However, interactions between fish size and feeding rate had higher significant effects on ash $(P<0.05)$. Fish fed with a feeding rate of $5 \% \mathrm{BW}$ had significantly lower ash compared with fish fed with $3 \% \mathrm{BW}$ and $7 \% \mathrm{BW}$.

Table 2: Effects of fish size and feeding rate on muscle composition throughout experimental period of 6 weeks of waigieu sea perch

\begin{tabular}{|c|c|c|c|c|}
\hline & Crude protein (\%) & Crude lipid (\%) & Moisture (\%) & $\operatorname{Ash}(\%)$ \\
\hline \multicolumn{5}{|c|}{ Treatments } \\
\hline SS3 & $17.8 \pm 30.46$ & $4.39 \pm 0.56$ & $75.74 \pm 1.52$ & $1.47 \pm 0.11$ \\
\hline SS5 & $18.31 \pm 0.62$ & $4.01 \pm 0.10$ & $75.00 \pm 1.18$ & $1.59 \pm 0.27$ \\
\hline SS7 & $17.70 \pm 0.54$ & $3.75 \pm 0.40$ & $72.95 \pm 1.11$ & $1.53 \pm 0.21$ \\
\hline BS3 & $18.71 \pm 1.12$ & $4.09 \pm 0.49$ & $75.33 \pm 1.19$ & $1.73 \pm 0.05$ \\
\hline BS5 & $18.80 \pm 1.05$ & $4.57 \pm 0.67$ & $73.58 \pm 1.39$ & $1.44 \pm 0.10$ \\
\hline BS7 & $18.13 \pm 1.09$ & $4.55 \pm 0.67$ & $75.36 \pm 1.84$ & $1.66 \pm 0.03$ \\
\hline \multicolumn{5}{|c|}{ Means of main effects of size } \\
\hline SS & 17.95 & 0.41 & 74.57 & 1.53 \\
\hline BS & 18.55 & 0.40 & 74.76 & 1.61 \\
\hline \multicolumn{5}{|c|}{ Mean of main effects of feeding rate } \\
\hline 3 & 18.27 & 4.24 & 75.54 & 1.60 \\
\hline 5 & 18.56 & 4.29 & 74.29 & 1.52 \\
\hline
\end{tabular}




\begin{tabular}{|c|c|c|c|c|}
\hline 7 & 17.92 & 4.16 & 74.15 & 1.60 \\
\hline \multicolumn{7}{|c|}{ Two-way ANOVA: P values } \\
\hline Fish size & 0.165 & 0.235 & 0.774 & 0.308 \\
\hline Feeding rate & 0.455 & 0.914 & 0.208 & 0.600 \\
\hline Fish size $\times$ Feeding rate & 0.882 & 0.278 & 0.086 & 0.102 \\
\hline
\end{tabular}

Values are displayed as mean of triplicate group's \pm SD. SS: small size; BS: big size.

\section{Physiological response}

There was no significant effect on feeding rate of 5\% and 7\% on white blood cell (WBC) $(P>0.05)$ whereas the high significant effect of feeding rate of $3 \%(P<0.05)$ (Table 3$)$. Fish fed 5\%BW had significantly higher WBC compared with fish fed with $7 \% \mathrm{BW}$ and $3 \% \mathrm{BW}$. Red blood cell (RBC) and hemoglobin (HB) was significantly affected by the feeding rate of $5 \%(P<0.05)$. However, there was a significant effect on feeding rate of $3 \%$ and $7 \%(P<0.05)$. Fish fed with the feeding rate of $5 \% \mathrm{BW}$ had significantly high $\mathrm{RBC}$ and $\mathrm{HB}$ than with fish fed with $3 \% \mathrm{BW}$ and $7 \% \mathrm{BW}$.

There was effect feeding rate of $5 \%$ and $7 \%$ on hematocrit (Hct) $(P<0.05)$. But there was significant effect of feeding rate of $3 \%(P<0.05)$. Fish fed with the feeding rate of $3 \% \mathrm{BW}$ had significantly lower Hct compared with fish fed with $5 \%$ and $7 \% \mathrm{BW}$. The Fish fed with the feeding rate of $3 \% \mathrm{BW}$ had no significantly of $\mathrm{MCV}, \mathrm{MCH}$ and $\mathrm{MCHC}$ compared with fish fed with $7 \%$ and $5 \% \mathrm{BW}$. There were no significant effect on feeding rate of $5 \%$ on Platelet $(P<0.05)$ whereas high significant effect of feeding rate of $3 \%$ and $7 \%(P<0.05)$. Fish fed with the feeding rate of $5 \% \mathrm{BW}$ had significantly high platelet compared with fish fed with $7 \% \mathrm{BW}$ and $3 \% \mathrm{BW}$.

The fish fed with a feeding rate of $5 \% \mathrm{BW}$ had significantly high triglyceride compared with fish fed with $7 \%$ and $3 \%$ BW. There was no significant effect feeding rate of $5 \%$ and $7 \%$ on protein blood $(P>0.05)$. But there was a significant effect of feeding rate of $3 \%(P<0.05)$. Fish fed with the feeding rate of $5 \% \mathrm{BW}$ had significantly high protein blood than with fish fed with $7 \%$ and $3 \%$ BW.

Table 3: Effects of feeding rate on hematological parameters of Waigieu Sea perch under the subjection of different feeding rates in the experimental period of $6 \mathrm{week}$ under intensive system conditions

\begin{tabular}{|c|c|c|c|}
\hline Parameters & $\mathbf{3 \%}$ & $\mathbf{5 \%}$ & $\mathbf{7 \%}$ \\
\hline $\mathrm{WBC}\left(\times 10^{3} / \mathrm{mm}^{3}\right)$ & $6.77 \pm 0.38^{\mathrm{a}}$ & $8.17 \pm 0.32^{\mathrm{b}}$ & $7.70 \pm 0.56^{\mathrm{b}}$ \\
\hline $\mathrm{RBC}\left(\times 10^{6} / \mathrm{mm}^{3}\right)$ & $2.27 \pm 0.45^{\mathrm{a}}$ & $3.27 \pm 0.35^{\mathrm{b}}$ & $2.63 \pm 0.51^{\mathrm{a}}$ \\
\hline $\mathrm{Hb}(\mathrm{g} / \mathrm{dL})$ & $7.67 \pm 0.55^{\mathrm{a}}$ & $9.23 \pm 0.06^{\mathrm{b}}$ & $8.27 \pm 0.42^{\mathrm{a}}$ \\
\hline $\mathrm{Hct}(\%)$ & $22.53 \pm 0.81^{\mathrm{a}}$ & $26.70 \pm 0.43^{\mathrm{c}}$ & $25.20 \pm 0.56^{\mathrm{b}}$ \\
\hline $\mathrm{MCV}(\mathrm{FL})$ & $102.71 \pm 25.06$ & $82.47 \pm 10.40$ & $97.90 \pm 17.35$ \\
\hline $\mathrm{MCH}(\mathrm{Pg})$ & $35.11 \pm 9.86$ & $28.49 \pm 3.09$ & $32.03 \pm 5.03$ \\
\hline $\mathrm{MCHC}(\mathrm{g} / \mathrm{dL})$ & $34.00 \pm 1.29$ & $34.59 \pm 0.67$ & $32.82 \pm 2.07$ \\
\hline Platelet $\left(\times 10^{9} / \mathrm{L}\right)$ & $24.00 \pm 2.65^{\mathrm{a}}$ & $30.33 \pm 2.08^{\mathrm{b}}$ & $25.33 \pm 1.53^{\mathrm{a}}$ \\
\hline Triglyceride $(\mathrm{mmol} / \mathrm{L})$ & $4.26 \pm 0.27$ & $5.56 \pm 0.95$ & $4.52 \pm 0.61$ \\
\hline Protein/blood $(\mathrm{g} / \mathrm{L})$ & $38.03 \pm 0.50^{\mathrm{a}}$ & $45.83 \pm 0.83^{\mathrm{c}}$ & $41.03 \pm 0.73^{\mathrm{b}}$ \\
\hline
\end{tabular}

Values are displayed as mean of triplicate group's \pm SD. Means with different lowercase alphabets within a row are significantly different $(P<0.05)$. WBC: white blood cell; Ht: Hematocrit, RBC: Red blood cell, $\mathrm{Hb}$ : Hemoglobin, MCV: Mean corpuscular volume, MCHC: Mean corpuscular hemoglobin concentration

\section{Discussion}

In the present study results leveled that feeding rate did not influence water quality for Waigieu seaperch growth. All parameters were in normal range and above feeding rate showed a significant effect on all growth performance parameters and feed efficiency indices (Table 1) indicated that waigieu sea perch fed $5 \%$ had significantly better growth in terms of FBW, WG, SGR than those fed with 3\% and 7\%. Similar results have been reported by (Deyab and Hussein
2015) ${ }^{[5]}$, the feeding rate is the crucial factors for growth performance (Gaber 2006) ${ }^{[8]}$.

There were significant difference in fish size $(P<0.05)$ observed on specific growth rate (SGR) which were similar on feeding rates but differ in the interaction between fish size and feeding rate similarly results was reported by (Cunha et al. 2013) ${ }^{[3]}$. It has long been recognized that overfeeding is more dangerous than underfeeding. Feeding greater than optimum feed level would increase the waste of food, increase feed conversion ratio and also deteriorate water quality which will increase the fish price (Charles et al. 1984) ${ }^{[2]}$.

FCR value in feeding rate of $5 \%$ was highly significantly different $(P<0.05)$ from values obtained in the other treatments the values obtained are showed a high feed utilization which was expressed as good growth performance and reduce the waste food as well as good water quality. While there was no significant difference in FCR among the fish size $(P>0.05)$. Whereas high value FCR obtained in $7 \%$ and $3 \%$ is the expression of increase the waste food and some level of water deterioration as well as lower growth performance. Similar results were reported by Deyab and Hussein (2015) ${ }^{[5]}$. Also, Channa striatus fed with 5\% body weight presented greater growth (Marimuthu et al. 2011) ${ }^{[17]}$.

In the present study, fed intake (IF) increase with increase feeding rates the high level of IF were recorded in the feeding rate of $7 \%$ while the lower values were recorded in feeding rate of $5 \%$ and $7 \%$ in all treatment groups (Table 1). There is sense in which increase of feed intake is proportion the growth performance. The result showed that PER in fish fed with5\% had higher values, than other feeding trials (Table 1), this results were in accordance with Berger and Halver (1987) ${ }^{[1]}$. Similar results have been reported in other fish species (Zhang et al. 2012) ${ }^{[23]}$, in contrast to our study, Kikuchi (1999) ${ }^{[9]}$ reported that PER values of olive flounder increased with increasing dietary protein levels. However, Dabrowski and Kozak (1979) ${ }^{[4]}$ reported that the relationship between dietary protein and PER differs from species to species. Therefore, fish size, physiological state, feed ingredient, rearing practices and rearing condition also need to be taken into account because they play a pivots role on determination of the optimum feeding rate and growth performance (Luo et al. 2006) ${ }^{[16]}$.

In this study, the results demonstrated that out of the parameters tested feeding rates causes significant differences in the levels of hematological parameters such as RBC and $\mathrm{Hb}, \mathrm{WBC}, \mathrm{Hct}, \mathrm{PLT}$ and Protein/blood of different feeding rate; while cause no significant in the $\mathrm{MCHC} \mathrm{MCH}$ and MCV. In the present study, the highest levels of WBC was noticed in the fish fed 5\% than other feeding rates in accordance with Fazio et al. (2013) ${ }^{[7]}$ reported that species with higher levels of WBC will be able to fight infection more effectively than other species.

In our study, the levels of RBC and $\mathrm{Hb}$ was the highest in fish fed $5 \%$ compared to other feeding treatment contrary to find that values of RBC, Hct and $\mathrm{Hb}$ increased with increasing fish size (Satheeshkumar et al. 2012) ${ }^{[22]}$. However, high RBC values were associated with fast movement, predaceous nature and high activity with streamlined bodies (Rambhaskar 
and Srinivasa Rao 1987) ${ }^{[19]}$. Furthermore, the increased number of RBC is the sign of oxygen demand in the tropical region species to meet the higher oxygen requirement at higher metabolic rates (Eisler 1965) ${ }^{[6]}$. The higher level of $\mathrm{Hb}$ in the feeding rate of $5 \%$ is the expression of the ability of oxygen carrying capacity of blood and the level of erythropoietic status.

In the figures of above (Table 3), also present values of hematological indexes of erythrocyte constants $\mathrm{MCV}, \mathrm{MCH}$ and $\mathrm{MCHC}$, the higher value of $\mathrm{MCV}, \mathrm{MCH}$ and $\mathrm{MCHC}$ was recorded in the fish fed with $3 \%$ followed by $7 \%$ and $5 \%$, amount hemoglobin within correspondence of concentration of erythrocyte constants indicate a good physiological condition of waigieu sea perch. Moreover, erythrocyte constants levels consider an indication of anemia (Radu et al. 2009) ${ }^{[18]}$. In the present study, the high value of platelet was observed in fish fed with $5 \%$ compared with other feeding trials, an increase of the number of platelet in blood are implication of plasma in fish blood. The result reveal that protein blood and triglyceride concentrations were noticed in the fish feed with $5 \%$ than other feeding trials

The result from (Table 2) revealed that different feeding rate did not significantly affect waigieu seaperch body composition. Nearly the same number of protein were observed in the fish fed with 5and 7\%body weight, while quite little difference was noticed in the fish fed with $3 \%$ body weight. The figure of protein concentration in the body composition expressed that different fed application in our study has the same effect on protein concentration. Whereas body moisture content of the fish feed with $3 \%$ body weight was higher than that fish fed at 5 and $7 \%$ body weight. Nevertheless, body lipid content of the fish fed at 5 and $7 \%$ body weight was almost nearly the same, but a little difference was noticed in the fish fed at 3\% body weight which are the implication of lower lipid content in fed used in our study. For the body ash content of the fish fed at 3 and $7 \%$ body weight was the same, though fish fed at $5 \%$ body weight was less ash content than others. In the present study, it appears that the daily feed application rate of $5 \%$ body weight was near to optimum when the fish grew from $17 \mathrm{~g}$ to $33.11 \mathrm{~g}$ for small size and $20 \mathrm{~g}$ to $33.78 \mathrm{~g}$ for big size and enhanced heamatological parameters. The results suggest that, although a feeding rate of $5 \%$ gave the highest growth performance, Waigieu Sea perch should be fed at the rate of $5 \%$ body weight per day, considering feed conversion efficiency and growth performance into account. In conclusion much attention should be paid on feeding

rates and strategies, as well as economic considerations, in order to optimize growth performance and heamatological parameters.

\section{Acknowledgements}

The financial support provided by Vietnam National Foundation for science and technology Development (NAFOSTED) under grant number 106.05-2017.343 is greatly acknowledged.

\section{References}

1. Berger A, Halver J. Effect of dietary protein, lipid and carbohydrate content on the growth, feed efficiency and carcass composition of striped bass, Morone saxatilis (Walbaum), fingerlings. Aquaculture Research 1987;18:345-356.

2. Charles PM, Sebastian SM, Raj MCV, Marian MP.
Effect of feeding frequency on growth and food conversion of Cyprinus carpio fry. Aquaculture 1984;40:293-300.

3. Cunha VLD, Shei MRP, Okamoto MH, Rodrigues RV, Sampaio LA. Feeding rate and frequency on juvenile pompano growth. Pesquisa Agropecuária Brasileira 2013;48:950-954.

4. Dabrowski K, Kozak B. The use of fish meal and soyabean meal as a protein source in the diet of grass carp fry. Aquaculture 1979;18:107-114.

5. Deyab ESD, Hussein EESM. Effects of different feeding rates on growth performance and body composition of red tilapia, Oreochromis mossambiquse $x$ O. niloticus, fingerlings. International Journal of Aquaculture 2015, 5.

6. Eisler R. Erythrocyte counts and hemoglobin content in nine species of marine teleosts. Chesapeake Science 1965;6:119-120.

7. Fazio F, Marafioti S, Arfuso F, Piccione G, Faggio C. Comparative study of the biochemical and haematological parameters of four wild Tyrrhenian fish species. Veterinarni Medicina 2013;58:576-581.

8. Gaber MM. The effects of plant-protein-based diets supplemented with yucca on growth, digestibility, and chemical composition of Nile tilapia (Oreochromis niloticus, L) fingerlings. Journal of the World Aquaculture Society 2006;37:74-81.

9. Kikuchi K. Use of defatted soybean meal as a substitute for fish meal in diets of Japanese flounder (Paralichthys olivaceus). Aquaculture 1999;179:3-11.

10. Le MH, Brown PB. Effects of time after hormonal stimulation on milt properties in waigieu seaperch Psammoperca waigiensis. The Israeli Journal of Aquaculture - Bamidgeh 2016, 68(9).

11. Le MH, Lim HK, Min BH, Lee JU, Chang YJ. Semen properties and spermatozoan structure of yellow croaker Larimichthys polyactis. The Israeli Journal of Aquaculture - Bamidgeh, 63, Accepted and online first 2011, 8.

12. Le MH, Nguyen THN, Pham PL. Semen properties of waigieu seaperch Psammoperca waigiensis. The Israeli Journal of Aquaculture - Bamidgeh 2014a, 66, 7.

13. Le MH, Nguyen TTT, Pham PL. Role of anitibiotics on chilled storage sperm motility of waigieu seaperch Psammoperca waigiensis (Cuvier and Valencienes, 1828). The Israeli Journal of Aquaculture - Bamidgeh 2014b, 66, 5 .

14. Le MH, Pham HQ. Sperm motilities in waigieu seaperch, Psammoperca waigiensis: Effects of various dilutions, ph, temperature, osmolality, and cations. Journal of the World Aquaculture Society 2017;48:435-443.

15. Le MH, Pham HQ. Seasonal changes in the milt quality of Waigieu seaperch, Psammoperca waigiensis: implications for artificial propagation. Journal of the World Aquaculture Society 2018;49:857-866.

16. Luo Z, Liu YJ, Mai KS, Tian LX, Tan XY, Shi JF. Effects of feeding levels on growth performance, feed utilization, body composition, and apparent digestibility coefficients of nutrients for grouper Epinephelus coioides juveniles. Journal of the World Aquaculture Society 2006;37:32-40.

17. Marimuthu K, Umah R, Muralikrishnan S, Xavier R, Kathiresan S. Effect of different feed application rate on growth, survival andcannibalism of african catfish, Clarias gariepinus fingerlings. Emirates Journal of Food 
and Agriculture 2011, 330-337.

18. Radu D, Oprea L, Bucur C, Costache M, Oprea D. Characteristics of haematological parameters for carp culture and Koi (Cyprinus carpio Linneaus, 1758) reared in an intensive system. Bulletin UASVM Animal Science and Biotechnologies 2009;66:336-342.

19. Rambhaskar B, Srinivasa Rao K. Comparative haematology of ten species of marine fish from Visakhapatnam Coast. Journal of fish biology 1987;30:59-66.

20. Rupasinghe JW, Kennedy JO. Optimal batch lengths for barramundi farming under seasonal variations: A dynamic programming approach 2006.

21. Salgado-Ismodes A, Taipale S, Pirhonen J. Effects of progressive decrease of feeding frequency and re-feeding on production parameters, stomach capacity and muscle nutritional value in rainbow trout (Oncorhynchus mykiss). Aquaculture 2020;519:734919.

22. Satheeshkumar P, Ananthan G, Kumar DS, Jagadeesan L. Haematology and biochemical parameters of different feeding behaviour of teleost fishes from Vellar estuary, India. Comparative Clinical Pathology 2012;21:11871191.

23. Zhang $\mathrm{Z}$, Yao $\mathrm{X}$, Wang $\mathrm{H}$. Potential application of geopolymers as protection coatings for marine concrete III. Field experiment. Applied Clay Science 2012;67:5760 . 